\title{
Erratum to: Searching for a listed infrastructure asset class using mean-variance spanning
}

\author{
Frédéric Blanc-Brude ${ }^{1}$. Timothy Whittaker ${ }^{1}$. \\ Simon Wilde ${ }^{2}$
}

Published online: 13 September 2017

(C) Swiss Society for Financial Market Research 2017

\section{Erratum to: Financ Mark Portf Manag (2017) 31:137-179 DOI 10.1007/s11408-017-0286-Z}

The article Searching for a listed infrastructure asset class using mean-variance spanning written by Frédéric Blanc-Brude, Timothy Whittaker, Simon Wilde was originally published Online First without open access. After publication in volume 31, issue 2, pages 137-179, the author decided to opt for Open Choice and to make the article an open access publication. Therefore, the copyright of the article has been changed to (C) The Author(s) 2017 and the article is forthwith distributed under the terms of the Creative Commons Attribution 4.0 International License (http://creativecommons.org/ licenses/by/4.0/), which permits use, duplication, adaptation, distribution, and reproduction in any medium or format, as long as you give appropriate credit to the original author(s) and the source, provide a link to the Creative Commons license, and indicate if changes were made.

The online version of the original article can be found under doi:10.1007/s11408-017-0286-z.

$\bowtie$ Frédéric Blanc-Brude

frederic.blanc-brude@edhec.edu

Timothy Whittaker

tim.whittaker@edhec.edu

Simon Wilde

s.g.wilde@bath.ac.uk

1 EDHEC Infrastructure Institute-Singapore, \# 07-02, One George Street, Singapore 049145, Singapore

2 University of Bath, Building 8 West, Quarry Rd, Bath BA2 7AY, UK 